\title{
6. Investigative journalism: Challenges, perils, rewards in seven Pacific Island countries
}

\section{ABSTRACT}

This article appraises the general state of investigative journalism in seven Pacific Island countries - Cook Islands, Fiji, Papua New Guinea, Samoa, Solomon Islands, Tonga and Vanuatu—and asserts that the trend is not encouraging. Journalism in general, and investigative journalism in particular, has struggled due to harsher legislation as in military-ruled Fiji; beatings and harassment of journalists as in Vanuatu; and false charges and lawsuits targeting journalists and the major newspaper company in the Cook Islands. Corruption, tied to all the major political upheavals in the region since independence, is also discussed. Threats to investigative journalism, like the 'backfiring effect' and 'anti-whistleblower' law are examined, along with some investigative journalism success case studies.

\section{SHAILENDRA SINGH}

\section{University of the South Pacific}

7 HIS article explores investigative journalism practice and capacity in seven Pacific Island countries, namely Cook Islands, Fiji, Papua

1 New Guinea, Samoa, Solomon Islands, Tonga and Vanuatu. It starts with a consideration of Fiji, which adopted stern media laws following the December 2006 coup. Fiji's situation is the most drastic in the region, and is studied in greatest detail. The article then considers the other six countries. Unlike Fiji, these countries are democracies in one sense or another. But their journalists still face harassment, especially if they criticise government. Some of the more blatant cases of persecution are revisited. Aside from state pressure, certain structural, environmental and organisational factors peculiar to the region also hinder investigative journalism. These are discussed, with some suggestions for mitigation. The link between corruption, instability and a litany of other ills such as poverty, crime and under-development 
is examined, with the writer maintaining that these problems highlight the need for supporting and strengthening investigative journalism in the Pacific. 'Big brother' Fiji's role in spreading the coup culture in the region, and the possibility of its media laws being emulated by neighbouring countries, is explored. Other topics include 'anti-whistleblower' legislation designed to stop damaging leaks and the 'backfiring effect' of investigative journalism. Despite the difficulties, the region's media have exposed some massive scams. Some of these examples are re-examined.

\section{Fiji}

One supporter of investigative journalism in Fiji is Attorney-General Aiyaz Sayed-Khaiyum, or so it seems. While addressing University of the South Pacific regional journalism students in Suva in October 2009, Sayed-Khaiyum made an impassioned plea for journalists to think outside the box and cover vital stories facing the nation. He added that journalists needed to be 'more analytical' and should 'investigate critical issues' often left out of the media (Think outside box, Pacific Scoop, 2009).

All very well, except that Sayed-Khaiyum is an appointee of the military regime that took power on 5 December 2006 in Fiji's fourth coup. Headed by coup leader and military commander, Commodore Voreqe Bainimarama, this regime has passed laws that has made the environment for everyday journalism, let alone investigative journalism, very challenging, to put it mildly. As Attorney-General, Sayed-Khaiyum would have signed off laws that are anathema to the very kind of journalism he was extolling in his talk. Seen under this light, Sayed-Khaiyum's speech was quite remarkable, to say the least. Elaborating on the issue, he said:

My question is that I am looking at it from a journalistic angle in terms of your ability, in terms of your freedom to be able to write what you want to write - of course, with the various responsibilities that go with it in terms of defamation. (ibid., para. 13)

Concerns about defamation aside, the 'freedom to be able to write what you want to write' that Sayed-Khaiyum speaks of is simply not there, the result of the most intense and relentless purge of the news media in the country's history, with both legalised and extra-legal methods used for curtailment. In the early days of the takeover, 'errant' journalists would either get a 'phone call' 
or a 'visit' by the military, or receive an 'invite' to the army camp. Further crackdowns began in earnest in April 2009 following a Fiji Court of Appeal ruling that declared the post-coup interim government unlawful.

In response to the judgment, Fiji's then President, the late Ratu Josefa Iloilo, revoked the 1997 Constitution, dismissed all senior judicial officers and reappointed Bainimarama as Prime Minister. The Public Emergency Regulations (PER) were instituted, giving sweeping powers to the Permanent Secretary of Information over the news media, and government censors access to all Fiji newsrooms to vet the news before publication.

Then, in June 2010, the regime gazetted the Media Development Decree and created the Media Industry Development Authority (MIDA) under new laws and guidelines for media practice. A statutory body, the Media Tribunal, was formed to handle media complaints, rendering self-regulation under the Fiji Media Council redundant. Under the newly-promulgated decrees, journalists and media companies faced jail terms and hefty fines for publishing anything 'against the public interest'. What constituted the public interest was ill defined. In an article called 'Life under Decree No. 29 of 2010: The Fiji Media Development Decree', this writer had questioned whether legitimate criticism of the regime was against the public interest (Singh, 2010).

On 7 January 2012, the Public Emergency Regulations were lifted. But celebrations were short-lived. Two days after being scrapped, the regulations were replaced by a similar legislation: The Public Order (Amendment) Decree 2012. This granted individual police officers discretionary powers to use force, including firearms, to disperse any gathering deemed a threat to public safety. The Citizens' Constitutional Forum Limited, a Suva-based non-governmental organisation that supports democracy and multiculturalism, condemned the new legislation as untimely and restrictive (Public Order Amendment Decree 2012 restricts basic freedoms, 2012).

This author had first-hand experience of how the media legislation affected journalism students enrolled at University of the South Pacific, where he was the Divisional Head of Journalism. Just before the law came into effect, student journalists had completed work on USP Journalism's award-winning training newspaper, Wansolwara, and sent it for printing. The newspaper contained a four-page Insight Report on media freedom in Fiji. Some aspects of the report were critical of the regime. When the announcement about the gazetting of the Media Development Decree became public, Wansolwara was still at the 
press. Wansolwara's Solomon Islands student editor was so concerned that he called this writer at night, wanting to know if he and his colleagues would get into trouble because of the Insight Report. The student was assured that it was unlikely they would be targeted, and that the lecturers would take full responsibility should there be any problems.

The student editor's concern was understandable given Fiji's highlypublicised media purge, which included the expulsion of three Australian expatriate newspaper publishers - The Fiji Times' Rex Gardner in January 2009, his predecessor Evan Hannah in May 2008, and the Fiji Sun's Russell Hunter in February 2008. Hannah and Hunter's expulsion were related to a series of investigative disclosures about the undeclared offshore bank accounts allegedly held by Fiji's former Prime Minister, Mahendra Chaudhry, who at the time was the regime's interim Finance Minister.

The Fiji Sun had run a series of articles written by United Kingdom-based Fiji-born author and Oxford University legal scholar, Victor Lal, alleging that Chaudhry held undeclared funds of around US\$1 million in Australian bank accounts. The funds were allegedly deposited by Indian government sources in the years after Fiji's 2000 coup, which ousted Chaudhry's government. Chaudhry was not named in the articles but his identity was an open secret. He did not respond to the allegations, except to say that the minister concerned had been cleared by internal inquiry. (Chaudhry's taxes; a background, 2008).

As pressure mounted, Chaudhry dared the media to name the minister. The Fiji Times took up the challenge, and on 23 February 2008, it ran a front page headline, 'It's Chaudhry'. The next day the Fiji Sun revealed that Chaudhry was the unnamed minister in question (ibid). Retribution was swift, with Fiji Sun's Hunter seized and bundled out of the country within days. In May, Hannah of The Fiji Times suffered a similar fate.

Lal and Hunter's efforts won them Fiji's Robert Keith-Reid Award for outstanding journalism in 2008. This writer was part of the four-member awards judging panel, which mentioned that the articles were courageously published in Fiji when the Bainimarama regime was in power. According to the citation, Lal displayed extraordinary persistence and skill in developing and uncovering the story in a series of articles over several months, with documentation obtained from sources prepared to take a risk (Musings on Fiji, 2010).

Hunter was recognised for supporting Lal, and the Fiji Sun for providing the professional context. The Fiji Times and its editor, Netani Rika, were award- 
ed a special commendation for being the first publication to reveal Chaudhry's name (ibid.). But this fine piece of investigative journalism came at a cost, with the regime tightening the noose on the media. These retributory actions are an example of the 'backfiring effect' of investigative journalism in Fiji.

While Fiji has the region's toughest media laws, journalists in other island countries also face serious obstacles when it comes to investigative reporting. This is covered in the next section.

\section{Challenges for media in other island countries}

The fixation on Fiji since the December 2006 coup has diverted attention from threats journalists in other Pacific nations face. The situation is examined here, starting with the Cook Islands.

\section{Cook Islands}

Cook Islands is the first country in the region to enact freedom of information laws, with freedom of expression guaranteed under its Constitution. Even then, things can get rough, especially for journalists who exhibit investigative tendencies. Consider the case of Helen Greig, a journalist with the Cook Islands News. Speaking at the UNESCO World Press Freedom Day conference at the University of Queensland in May 2010, Greig gave a harrowing account of her experience at the hands of police because of her articles on government corruption (Reporter Speaks out about trespassing case, 2010). Based on a complaint filed by an official, a six-month pregnant Greig was summoned to the police station, made to undergo a three-hour interrogation, and charged with trespass under a 50-year-old rarely used legislation. Even before her first court appearance, she was pronounced guilty on Radio NZ by a senior Cook Islands police official. A court case she attended was adjourned before she was finally informed that the charges against her had been dropped (ibid). The managing editor of Cook Islands News, John Woods, stated that the reporting environment in the country was tough, with the open expression of opinions on contentious issues drawing scorn and legal threats on a weekly basis:

Despite our Official Information Act, the Cook Islands is being denied its right to know at the highest level. The most powerful entity of government, Cabinet, is still a stronghold of secrecy and non-disclosure. (Woods, 2010, para. 13) 
Cook Islands News has been served with several defamation cases, including a \$US1.3 million lawsuit taken out by hotelier Tata Crocombe and Lady Carla Davis in 2008. Lawsuits are effective for seeking redress against genuine misconduct by the media. But they can also be used to intimidate journalists, stall their investigations and inundate media companies with legal bills. Chaudhry threatened to sue The Fiji Times for FJD\$1 billion when the paper named him as the minister involved in the offshore bank account controversy (Chaudhry's taxes; a background, 2007).

\section{Samoa}

Prime Minister Tuilaepa Sailele Malielegaoi has vigorously attacked Bainimarama, calling him a dictator (Samoa PM says there will be no Fiji election, 2012). But critics say the Samoan government is hardly a beacon for media freedom, having pioneered some of the region's toughest media legislation. Samoa's Publishers and Printers Act does not permit journalists to protect sources, and requires they be named (Larmour \& Barcham, 2005. p. 7). This is an example of an 'anti-shield' law, or an 'anti-whistleblower' law. Fiji has similar legislation, with mandatory fines or jail terms for non-compliance. Another Samoan law allows government ministers to sue media outlets with taxpayer money. A criminal libel law under which Samoan publisher Savea Sano Malifa was charged in 1997 still exists (Criminal libel law challenged, 1997).

More recently Malielegaoi was criticised by Samoa Observer editor Mata'afa Keni Lesa over his failure to deliver on a promise to publish an audit report of the US\$2 million received in public donations for Samoa's Rugby World Cup team. Keni Lesa quipped that Samoa needed an 'International Anti-Corruption Day' (Brown, 2012). The Prime Minister was also accused of dodging queries about the disbursement of $\$ 107$ million tsunami relief aid. He responded to a NZ TV3 Campbell Live programme on the subject by filing an action against the report. But the NZ Broadcasting Standards Authority (BSA) ruled against the complaint, and in November 2011 the story won John Campbell the Aotearoa Film and Television Award for Investigation of the Year (Perrottet, 2011).

\section{Papua New Guinea}

Papua New Guinea has a track record of politicians, military, criminal gangs and tribal groups targeting journalists. In a case in the capital Port Mores- 
by in March 2012, Post Courier journalist Patrick Talu was assaulted by a policeman and warned that he would be blown up with a hand grenade (Police threaten to 'blow up' Post-Courier journalist, 2012). This was the second such incident in 2012. It underlined the volatile and unpredictable environment Papua New Guinean journalists operate in.

In the earlier incident in January 2012, soldiers at the Murray Barracks in Port Moresby threatened to shoot PNGFM reporter Tauna George during the failed mutiny crisis. On the same day, ABC PNG stringer Firmin Nanol was denied access to a press conference. The threats to Papua New Guinea media came amid weeks of increasing incidences of self-censorship within industry ranks due to intimidation in recent months (PNG FM reporter threatened, 2012).

In 2002, Post Courier reporter Robyn Sela was investigating a corruption case at the military barracks in Port Moresby when a soldier threatened to 'shoot her dead' if she persisted (Attacks on the Press 2002: Papua New Guinea, 2003, para. 2). Such threats are not to be taken lightly in PNG and Sela went AWOL for a while. The 2010 US Department of State Human Rights Report on Papua New Guinea found no evidence of officially sanctioned government censorship, but it reported that journalists complained of intimidation tactics aimed at influencing coverage. In March 2010, Prime Minister Sir Michael Somare threatened to call reporters before the Parliamentary Privileges Committee to oblige them to reveal the names of politicians allegedly linked to crime. The threat was not carried out (US Department of State, 2011).

Dr Evangelia Papoutsaki, co-editor of Communication, Culture and Society in Papua New Guinea: Yu Tok Wanem? highlighted another problem affecting journalistic standards in Papua New Guinea-poor pay, which was forcing journalists to flee the industry. Papoutsaki stated that the high turnover meant that journalists didn't get time to make an impact in the industry (PNG's media industry hit by poor pay, 2012). Lack of depth in the newsroom is a region-wide problem and a blow to investigation journalism, which is handicapped without experienced reporters. Media ownership in Papua New Guinea further complicates issues. The country's leading daily, The National, is owned by the Malaysian logging company Rimbunan Hijau. The company has major interests in the country's forestry, a sector rife with corruption (Zwartz, 2010). 


\section{Solomon Islands}

Solomon Islands faces a more stealthy threat to investigative journalismone that is internal to the news media industry. The size of the private media sector in the Solomon Islands is small, which can lead to problems of its own kind. According to Larmour and Barcham (2005), a privately-owned press is not necessarily more critical. In the Solomon Islands' case, the press was 'free but docile'. Its 'narrow ownership base' and publisher's links to the elite led to self-censorship (p. 7). Even then, Solomon Islands media has played a part in exposing corruption, states the chairman of the Solomon Islands chapter for Transparency International, Bob Pollard. He believes investigative journalism can help uncover irregularities in both government and the private sector (The role of media, Island Sun, 2011, para. 11).

\section{Tonga}

The island kingdom became infamous for the persistent persecution of newspaper publisher Kalafi Moala for his publication's investigations into the royal family's financial dealings. The determination with which the authorities pursued Moala and the lengths they were willing to go in their attempts to muzzle his paper were overwhelming. Tonga even took to amending its Constitution to allow it to ban newspapers, although it did not stand up in court. Recently the country toyed with the idea of changing its Constitution to adopt a Fiji-like media law but shelved the proposal, apparently in response to criticism (Singh, 2010). The Pacific Freedom Forum (PFF), a regional media network, believes removing Tonga's constitutional protection of a free media should not be done without a full public discussion. Said then PNG-based PFF chair Susuve Laumaea:

Worldwide, government control over press freedom in the name of 'sensitivity' and 'responsibility' always translates into shutting down debate on the issues that matter most to citizens - and restricts them of their universal human right to freedom of expression. (Media freedom threatened in Tonga, 2010, para. 3)

Given that the Tongan government already controls the broadcast environment, including content, it was understandable that its overtures regarding the print media raised concerns. 


\section{Vanuatu}

In Vanuatu, some take matters into their own hands when unhappy with the media - literally. Vanuatu Daily Post publisher Marc Neil-Jones found this out the hard way. He has been assaulted at least thrice for reports published by his newspaper. The latest attack on March 2011 was carried out by supporters of the Public Utilities and Infrastructure Minister, Harry Lauko. It followed the publication of a report linking Lauko to maladministration in Port Vila, and took place at the newspaper's office. The assailants used a government vehicle for the 'operation'. An angry Lauko threatened the paper's editor, Royson Willie, saying 'yu wantem mi brekem face blo yu?' (Do you want me to break your face?) (Pacific media condemn minister, 2011).

Police were criticised for taking their time to charge Lauko. He was eventually fined US\$150, drawing the ire of Neil-Jones and others (Vanuatu publisher may appeal, 2010). In January 2009 Neil-Jones was assaulted by Correctional Service officers over a news article and in 2000 he was deported by then Prime Minister Barak Sope for publishing 'state secrets'—including news that eventually got Sope convicted in court (Pacific media condemn minister, 2011).

\section{Non-governmental threats to investigative journalism}

Larmour and Barcham (2005), raise an important point when they point out that a privately-owned press is not necessarily more critical, as in the case of the Solomon Islands. Normally, all eyes are on threats from governments and other powerful actors. But there are weaknesses and susceptibilities inherent within the Pacific Island news media structure, system and environment that also pose a risk to investigative journalism.

Even without having to deal with hostile governments, routine, day-to-day reporting (let alone investigative journalism), can be a major challenge in the Pacific. This is due to the lack of resources, training, formal qualifications, and technical expertise in specialist fields such as finance. One of the last investigative journalism workshops of any note for Pacific Island journalists was conducted in 2000 and 2001 by staff from the University of Queensland's Centre for International Journalism (see Tanner \& McCarthy, 2001).

Time and resources, crucial for investigative journalism, are often in short supply in the best of newsrooms, let alone in under-resourced Pacific Island newsrooms. For short-staffed Pacific Island editors, investigative journalism could well be a 'luxury' they cannot afford. If a prolonged investigation turns 
in nothing, editors would be disinclined to repeat their 'folly' and go on another wild goose chase. They may decide to stick to the more reliable 'here and now' bread and butter news stories.

Indeed, many exposés by Pacific Island media relied on records that had become public, such as auditor-general reports, or documents that 'fell off the back of a truck'. Exposés based on long, drawn-out investigations are few and far between, a point picked up by Larmour (2006) in his corruption report on the Pacific. He said that while there was a heroic tradition of investigative reporting, the media more routinely depended on official reporting and judicious leaks.

While this might not appeal to purists, Pacific Island media have little time for pretences, stripped as they are of resources, and having to improvise much of the time. Pacific Island media are usually happy to publish articles that fall into their laps. The fact that most media companies will publish controversial information even though it can get them into trouble, is in itself a great public service.

\section{Some infamous exposés}

Corruption is a major problem in parts of the region. According to Collier (2009), public money in poor countries is only put to its proper uses if politicians and senior public servants are shielded from temptation by systems of scrutiny and punishment. The Pacific Island news media is a system of scrutiny. Despite lacking expertise and resources, journalists have uncovered some major scandals. Some of the more infamous ones include the passport sales scandal in Tonga in the 1980s and in Samoa in the 1990s; the National Bank of Fiji scandal in the 1990s; Taiwan 'cash for recognition' scandal in Papua New Guinea in 2008; ongoing logging industry scandals in the Solomon Islands; national pension fund scandal in Vanuatu in 1998, and the \$81 million Sheraton scandal in the Cook Islands.

The uncovering of the National Bank of Fiji loans scam by The Review monthly magazine stands out as probably the best example of investigative journalism in Fiji and the region [the writer would like to declare his interest here as a former employee of The Review]. This was Fiji's biggest banking scandal, with a recorded loss of \$FJD372 million, according to former Fiji Reserve Bank Governor Sada Reddy (Raising investment a challenge, 2010). Inside sources, including financial experts, leaked documents that exposed 
the extent of the rot. The Review's 14-page exclusive report detailed the loans taken out by high-profile debtors who were making no effort to pay them back. The Review editor Yashwant Gaundar received the first Pacific Investigative Journalism Award in 1996 for the report (Pacific Investigative Journalism Award, 1996). According to the citation:

The article pieced together the maze of relevant facts. It unearthed new information and interviewed major players in the matter and provided the reader with a compelling account of corruption and incompetence within a country's major financial institution. The journalist used a range of investigative techniques, from relentless pursuit of a wide range of sources, to researching companies and individuals associated with the bank. (Robie, 2008)

The cases outlined so far are by no means a complete or exhaustive list of offences implicating governments and public officials, but it gives some indication of the seriousness of the problem, and how debilitating it can be for small Pacific Islands with struggling economies. According to Barcham (2007), corruption and malfeasance in Pacific countries can also be found in the following sectors: police, customs, land and titles administration, mineral and petroleum extraction, forestry, fisheries, ports, health, education, tendering, and trade in tokens of sovereignty, such as passports and internet domain names.

It is little wonder then that some Pacific Island countries do not score well on international corruption benchmarks. Five of the seven countries discussed in this paper were surveyed for the 2010 Transparency International Corruption Perceptions Index assessing corruption in 178 countries. All scored below five on a scale from 10 (highly clean) to 0 (highly corrupt).

Table 1: 2010 Pacific corruption perceptions
\begin{tabular}{|c|c|c|}
\hline Rank (out of 178) & Country & Score \\
\hline 73 & Vanuatu & 3.6 \\
\hline 91 & Kiribati & 3.2 \\
\hline 101 & Tonga & 3.1 \\
\hline 110 & Solomon Islands & 2.8 \\
\hline 154 & Papua New Guinea & 2.15 \\
\hline
\end{tabular}

Source: Ranking adapted from Transparency International 2010 Corruptions Perceptions Index. 
These rankings show that corruption is an ongoing problem. Naming and shaming by the media is considered a deterrent. But this theory does not always work in the Pacific Islands, where naming does not necessarily lead to shaming. Regardless of the challenges, there can be no letting up on media efforts to investigate and expose corruption given its links to a litany of ills. Corruption exacerbates poverty, hinders national development, lowers investor confidence, worsens gender inequality, presents a barrier to economic and institutional engagement by the poorest, aggravates ethnic inequality, results in unsustainable exploitation of natural resources, reduces public revenues and diverts public expenditure from essential services (Synexe Consulting Limited, 2007, p. 2). A Transparency International report highlights why the battle against corruption needs to be ongoing:

With governments committing huge sums to tackle the world's most pressing problems, from the instability of financial markets to climate change and poverty, corruption remains an obstacle to achieving muchneeded progress. (Response to global crises, Transparency International, 2010)

Furthermore, corruption is tied to all the major upheavals seen in regional countries since independence. This is discussed next.

\section{Link between corruption and instability in the Pacific}

Various scholars have highlighted how corruption and instability feed off each other (Fredriksson \& Svensson, 2003) and how this stunts overall growth (Hodge, Shankar, Prasada, \& Duhs, 2011). Five of the seven countries in this study have experienced instability because of corruption. They include Vanuatu, Solomon Islands, Tonga, Fiji and Papua New Guinea. In January 1998, Vanuatu's capital Port Vila was rocked by rioting over politicians' alleged misuse of the national pension funds (Boege \& Forsyth, 2007). In April 2006, widespread disturbances took place in the Solomon Islands capital, Honiara, following the announcement that controversial politician Snyder Rini had been appointed Prime Minister (Singh \& Prakash, 2008, p. 126). In September 2006 Tonga experienced an uprising in the capital, Nuku'alofa, by disaffected people seeking greater accountability from the royal family, who were perceived to be corrupt (Singh \& Prakash, 2008).

All of Fiji's four coups were arguably linked to corruption. The master- 
minds of the latest one in December 2006 dubbed it a 'clean-up campaign' against ousted Prime Minister Laisenia Qarase's allegedly corrupt government. But opponents of coup leader Bainimarama accused him of corruption after he collected a huge 30 -year back pay.

Corruption and bribery at the highest levels were also the triggers for failed businessman George Speight's so-called 'civilian coup' in May 2000, according to a 2003 FBI report. Speight was allegedly appointed chairman of the Fiji Hardwood Corporation by the Rabuka government to safeguard the financial interests of key government members skimming funds from the state's pine and mahogany plantations (FBI report says corruption behind Fiji coup, 2003). Sacked by the incoming Labour-Coalition government, Speight reinvented himself and returned as the self-proclaimed champion of indigenous Fijians to topple Chaudhry, Fiji's first Prime Minister of Indian descent. It is not inconceivable that Speight had other motives. Consider Campantey, Chor and Do (2008), who point out that access to public office provides opportunities for extracting corrupt rents through lucrative projects or the exploitation of natural resources. Often, these contracts take time to deliver their full monetary returns, and they can be halted if the incumbent is removed (2008, p. 1). This scenario aptly describes the situation Speight found himself in. Before his unceremonious removal, Speight was sitting on millions of dollars' worth of State mahogany plantations ready for harvest. It is quite likely that he teamed up with coup plotters in a bid to regain lost privileges.

Like Speight, Rabuka was encouraged by losing politicians to stage the 1987 coup. Years later Rabuka pointed an accusing finger at others, including former Prime Minister, the late Ratu Sir Kamisese Mara, defeated in the 1987 elections by the Labour-Coalition Party. Rabuka complained that he was made the 'fall guy' for others who refused to fall. But Mara denied such charges (Lal, 2010).

\section{Regional impact}

The repercussions of the Speight, Rabuka and Bainimarama coups were felt beyond Fiji's shores. They are thought to have inspired an armed takeover of the Solomon Islands government by rebel elements in June 2000, at the height of the ethnic conflict in the country. Prior to that, there were the army mutinies in Papua New Guinea in March 1997 and March 2001; and the armed forces rebellion in Vanuatu in 1996 (Henderson \& Bellamy 2002). 
Concerns about a coup cycle in the region persist, especially in the face of ongoing corruption. Marie-Noelle Ferrieux-Patterson, the president of Transparency International Vanuatu, believes the country could face a coup unless political corruption is firmly dealt with (Warning that Vanuatu corruption could lead to coup, 2011).

Apart from the coup cycle, there are concerns that Fiji's media laws could set a precedent among neighbouring island countries. These countries have long wanted to clip their media's wings, but balked because they feared an international backlash (Singh, 2010). But Fiji's example has shown that the international community can only do so much. There was an international clamour when Fiji first introduced its media legislation, but it faded away. Eventually the regime was able to bring the media to heel without any major repercussions from abroad. This could serve as an inspiration for other governments in the region.

Indeed, there were calls from Tonga about adopting media legislation similar to Fiji but the idea was shelved. Papua New Guinea Prime Minister Sir Michael Somare appeared to approve of Fiji's media decree when he told his country's journalists they were fortunate that similar laws had not been implemented in PNG (Singh, 2010). The Cook Islands also, has a draft media bill that the government resurrects from time to time. In 2008, a Cook Islands News editorial called for the scrapping of the media bill, which it described as 'ill-conceived, insidious and against democratic principles' (Scrap the bill, 2008).

\section{Anti-whistleblower legislation}

Legislation in Fiji and Samoa that mandates journalists disclose their sources are examples of anti-whistleblower laws designed to stop damaging leaks. Under the Fiji Media Development Decree, journalists who refuse to reveal confidential sources face fines of up to $\$ 10,000$, or jail terms of up to two years (Singh, 2010). Media is exempt from the law if the source reveals corruption by a public officer. But such legislation still goes against expert advice. Governance professor Ron Duncan believes small Pacific Island countries need shield laws to encourage whistleblowing because the secretive nature of white collar crime makes it harder to detect and convict (Call to shield those who expose corruption in Fiji, 2005).

It goes without saying that if other countries follow in Fiji's footsteps and adopt strong media legislation, government corruption will be harder to 
detect and report. Given the perceptible link between corruption, instability and stunted development, a free and fair media that is able to carry out its investigative work without undue hindrance is important for the region. But this is not easy to achieve due to, among other things, the backfiring effects of investigative journalism.

\section{Backfiring effect}

By 'backfiring effect', this writer is referring to the retaliatory actions taken against news media writers and publishers by parties revealed in and antagonised by the exposés. Such actions can take their own peculiar forms in $\mathrm{Pa}$ cific Island countries. In a non-democratic environment like Fiji, it can mean a visit or phone call by the military, or an invitation for a chat at the army camp, where some journalists claim they were roughed up. If you happen to be an expatriate publisher in Fiji, getting on the wrong side of the regime can mean a free passage back home.

Even in democratic countries the police can, and have been, used to lay trumped-up charges against investigative journalists, as in the Cook Islands, or ordered to go easy on assault and other complaints filed by journalists, as in Vanuatu. In PNG the backfiring effect took the form of unambiguous threats against journalists' lives. Whatever its shape, the backfiring effect is a menace to investigative journalism in Pacific Island countries. It can lead to intimidation, demoralisation and humiliation of journalists, throwing them off their tasks.

\section{IFJ calls for better protection}

Recent attacks on Pacific Island journalists have drawn the attention of the International Federation of Journalists (IFJ). On May 2009, the IFJ joined 40 Pacific Island journalists from 12 countries to call on Pacific Island governments to defend and promote media freedom in line with their obligations under Article 19 of the Universal Declaration of Human Rights. The journalists expressed deep concerns about increasing violations of media rights across the region. Draconian restrictions on the media in several Pacific Island countries were also seen as a major difficulty (International Federation of Journalists, 2009).

All the countries in this survey except the Cook Islands, were part of the Freedom of the Press 2011 index survey conducted by Freedom House. The survey covered 196 countries and territories, with each country consigned 


Table 2: 2011 Pacific press freedom global rankings
\begin{tabular}{|c|c|c|c|}
\hline Rank (out of 196) & Country & Rating & Status \\
\hline 48 & Papua New Guinea & 25 & Free \\
\hline 48 & Vanuatu & 25 & Free \\
\hline 61 & Solomon Islands & 29 & Free \\
\hline 65 & Samoa & 30 & Free \\
\hline 69 & Tonga & 31 & Partly free \\
\hline 124 & Fiji & 57 & Partly free \\
\hline
\end{tabular}

Source: Ranking adapted from Freedom of the Press 2011 Global Press Freedom Rankings (Freedom House).

a numerical rating ranging from 0 (the most free) to 100 (the least free). The rating serves as the basis for a press freedom status designation of Free, Partly Free, or Not Free. While an occasional Freedom House index ranking is not always a full reflection of the actual realities on the ground, it does give a reasonable indication of the situation.

The rankings show that apart from Fiji, there were relatively minor media freedom violations in 2010. However, in PNG's case, the 2011 US State Department Report cited Prime Minister Somare threatening to call reporters before the Parliamentary Privileges Committee in March 2010 (US Department of State, 2011). Papua New Guinea and Vanuatu managed to get 'free' status rankings but at 48 points they were still some way down the ladder. The Solomon Islands and Samoa also received 'free' ratings, but they were even further below Papua New Guinea and Vanuatu. Tonga's partly free status is justified. Fiji got a partly free ranking also, even though it has far more media restrictions than Tonga. Due to the entrenchment of prepublication censorship and a tough media law regulating content, Fiji registered the world's largest score decline. Vanuatu's score declined due to the harassment of the Vanuatu Daily Post publisher (Freedom of the Press, 2011, p. 7).

A comprehensive 39-page report on Pacific media freedom over the past year by Pacific Journalism Review states that media freedom in the region is fragile, notably in Fiji and Vanuatu, where blatant intimidation has continued with near impunity (Perrottet $\&$ Robie, 2011). The most serious case of media freedom violations in the Pacific is in West Papua, with at least two journalists killed, five abducted and 18 assaulted (p. 148). 


\section{Improving investigative journalism}

Investigative journalism in island countries faces major challenges because of a number of structural, cultural, organisational and environmental factors. But the unique circumstances in the Pacific can also be a comparative advantage. For one, investigative journalism can have a greater impact if there is greater collaboration. Such collaboration can occur among media companies, community-based organisations, academia and religious bodies. This is especially appropriate for Pacific Island countries because as pointed out by Swain (2000), community-based organisations proliferate and form a vital feature of life in island nations. Academia and NGOs can support news media in specialist areas. Churches, which wield a fair amount of moral authority and influence in the islands, can speak out against the persecution of journalists and provide sanctuary when necessary. But no formal or informal agreements exist to support such arrangements. Another level of cooperation can occur across borders between local media and their overseas counterparts. To some extent, this is already happening: Samoa's 2007 baby adoption scam involving American couples was jointly investigated by the Samoan Observer and Television New Zealand. In places where journalists are shackled by harsh laws, information can be passed onto the overseas news media for publication. Some journalists believe this is not happening. Samoa's Savali newspaper editor Tupuola Terry Tavita has berated Fiji journalists for their failure to use regional media networks to have their censored stories published elsewhere (Samoa's Savali blasts 'propaganda-promoting journalists', 2011).

In small markets it makes sense to pool scarce resources and share knowledge. But in Fiji, one media organisation will rarely follow up a story reported by another. Award-winning Fiji journalist Stanley Simpson investigated and exposed several suspect corporate-Government dealings as editor of the local magazine, Mai Life. But few, if any of his stories, were followed up by other Fiji news media despite their significance.

An example of how investigative stories can have a greater impact if the media work together was seen during the National Bank of Fiji exposé. The Review broke the story and The Fiji Times picked it up and ran with it. The Review had limited circulation, and it was The Fiji Times, Fiji's largestselling newspaper, which made the scandal accessible to a wider audience. There was a backfiring effect against The Review, and initially it stood alone 
against government attacks. But as other media followed up the story, there was a sense of solidarity and security in numbers.

The examples of Mai Laif and The Review (the latter is now out of publication) show that in Fiji monthly magazines may have a comparative advantage when it comes to investigative reporting. Comparative advantage is an economics concept. Countries, firms, people have comparative advantage if they can produce a good or service at lower cost than anyone else. Applying this concept to news magazines in Fiji, they normally have lower overhead costs than newspapers. They also have more time for investigative research.

The theory that investigative journalism is commercially unviable does not, in this writer's considered opinion, apply to monthly magazines in Fiji, and probably other Pacific Islands. To the contrary, magazines have strong commercial incentives to carry out investigative journalism. Breaking major stories can actually boost circulation and improve a magazine's stock. The Review, an obscure magazine with a niche readership, became a household name after breaking the National Bank of Fiji scandal. The magazine became more famous when it reported former Prime Minister Rabuka's relationship with a female journalist (see Rabuka and the reporter, Pacific Journalism Review, 1994). Pacific Island newspapers are unable to provide in-depth coverage and analysis due to resource constraints. This is a gap that magazines can fill. Fiji news magazines have been handicapped by lack of capital, marketing expertise and experience. But both The Review and Mai Laif have an excellent record in investigative journalism.

\section{Conclusion}

A lack of capacity combined with a repressive environment makes investigative journalism a major challenge in Pacific Island countries. Despite the difficulties, investigative journalism has played an important role in exposing the rot in the private and public sectors. Given the insidious nature of corruption and its destabilising effect in the region, it makes sense to support and strengthen investigative journalism capacity in the islands. While newspapers find it hard to carry out investigative journalism due to resources and time constraints, Fiji's example has shown that monthly news magazines have a comparative advantage in this area. With the media struggling against threats such as repressive governments and lack of resources and expertise, there is a need for external support to build capacity in the Pacific Islands. 
Media can overcome some of these constraints by working with the competition on major stories and collaborating with other institutions central to life in the Pacific Islands, such as community-based civil society organisations and the church.

\section{References}

Attacks on the Press 2002: Papua New Guinea. (2003, March 31). Committee to Protect Journalists. Retrieved on 24 August 2011, from www.cpj.org/2003/03/ attacks-on-the-press-2002-papua-new-guinea.php

Barcham, M. (2007). Corruption in Pacific Island countries. Suva, Fiji: UNDP Pacific Centre.

Boege, V., \& Forsyth, M. (2007, December 7-8). Customary conflict resolution in a state environment - cases from Vanuatu. Unpublished paper presented at the 10th Pacific Islands Political Studies Association (PIPSA) Conference, Port Vila.

Brown, J. (2012, January). Pacific Update: Corruption and Samoa's bright future. Islands Business. Retrieved on 1 February 2012, from www.islandsbusiness. com/islands_business/index_dynamic/containerNameToReplace=MiddleMiddle/ focusModuleID=19988/overideSkinName=issueArticle-full.tpl

Call to shield those who expose corruption in Fiji. (2007, March 5). Radio New Zealand International. Retrieved on 29 August 2011, from www.cinews.co.ck/2010/ May/Wed05/features.htm

Chaudhry's taxes; a background. (2008, March 18). Retrieved on 31 January 2012, from www.michaelfield.org/chaudhry\%20tax.htm

Collier, P. (2009). Wars, guns and votes: Democracy in dangerous places. London: The Bodley Head.

Criminal libel law challenged. (1997, November 21). Pacific Media Watch. Retrieved on 24 August 2011, from www.pmw.c2o.org/docs/no24sam.html

Dorling, P. (2011, September 4). PNG exposed as 'dysfunctional blob'. Smh.com. au. Retrieved on 4 September 2011 from www.smh.com.au/world/png-exposedas-dysfunctional-blob-20110903-1jrcx.html

FBI report says corruption behind Fiji coup. (2003). Pacific Media Watch. Retrieved 24 August, 2011, from www.asiapac.org.fj/cafepacific/resources/aspac/fiji3908.html

Fredriksson, P., \& Svensson, J. (2003). Political instability, corruption and policy formation: the case of environmental policy. Journal of Public Economics, 87, pp. 1383-1405.

Freedom of the press 2011. (2010). Signs of change amid repression. Retrieved on 29 August 2011, from www.freedomhouse.org/uploads/fop11/FOTP2011Booklet.pdf Henderson, J., \& Bellamy, P. (2002). Prospects for further military intervention in Melanesian politics. World Affairs, 164(3), pp. 124-133.

Hodge, A., Shankar, S., Prasada, R., \& Duhs, A. (2011). Exploring the links between corruption and growth. Review of Development Economics, 15(3), pp. 474-490. 
International Federation of Journalists. (2009, May 10). IFJ joins Pacific call for action on media freedom. Retrieved on 29 August 2011, from www.ifex.org/ international/2009/05/12/ifj_joins_pacific_call_for_action/

Lal and Hunter win Fiji's top journalism award. (2010). Retrieved on 1 January 2012, from http://victorlal.blogspot.com.au/

Lal, B. (2010, June 8). Tuimacilai: A review essay. Retrieved 1 January 2012, from http://intersections.anu.edu.au/pacificurrents/lal_review.htm

Larmour, P. (2006, March 30). Culture and corruption in the Pacific Islands: Some conceptual issues and findings from studies of National Integrity Systems. Policy and Governance Discussion Paper 06-05. Canberra, Australia: Asia-Pacific School of Economics and Government, The Australian National University.

Larmour, P., and Barcham, M. (2005). Integrity systems in small Pacific island states. Policy and Governance Discussion Paper 05-9. Canberra, Australia: Asia-Pacific School of Economics and Government, The Australian National University.

Media freedom threatened in Tonga. (2010). Pacific Freedom Forum. Retrieved on 1 February 2011, from www.pacificfreedomforum.org/2010/07/media-freedomthreatened-in-tonga-as.html

Media industry hit by poor pay, says book editor. (2012, March 15). Pacific Media Watch. Retrieved on 15 March 2012, from http://pacific.scoop.co.nz/2012/03/ pngs-media-industry-hit-by-poor-pay-says-book-editor/

Pacific Investigative Journalism Award: What the judges said. (1996). Pacific Journalism Review, 3(2), pp. 156-158.

Pacific media condemn minister 'and his thugs' for attack on Daily Post. (2011, March 5). Pacific Scoop. Retrieved on 3 September 2011, from http://pacific. scoop.co.nz/2011/03/pacific-media-condemn-minister-and-his-thugs-for-attackon-daily-post/

Perrottet, A. (2011, November 17). Campbell Live: Award for Samoa tsunami money investigation. Pacific Media Centre. Retrieved on 2 January 2012, from www. pmc.aut.ac.nz/pacific-media-watch/nz-campbell-live-wins-award-samoa-tsunamimoney-investigation-7729

Perrottet, A., and Robie, D. (2011). Pacific media freedom 2011: A status report. Pacific Journalism Review, 17 (2), pp. 148-186. Retrieved on 1 March 2012, from www. pjreview.info/articles/special-report-pacific-media-freedom-2011-status-report-513

PNG reporter threatened during mutiny, says advocacy group. (2012, February 2). Pacific Media Centre Online. Retrieved 24 August, 2011, from www.pmc.aut. ac.nz/pacific-media-watch/png-png-fm-reporter-threatened-during-mutiny-saysadvocacy-group-7808

PNG's media industry hit by poor pay, says book editor. (2012, march 14). Pacific Scoop. Retrieved 24 August, 2011, from http://pacific.scoop.co.nz/2012/03/pngsmedia-industry-hit-by-poor-pay-says-book-editor/

Police threaten to 'blow up' Post-Courier journalist. (2012, March 8). Pacific Media Centre. Retrieved on 8 March 2012, from www.pmc.aut.ac.nz/pacific-media-watch/ png-police-threaten-blow-post-courier-journalist-7847 
Public amendment order decree 2012 restricts basic freedoms. (2012). Citizens Constitutional Forum. Retrieved 24 August, 2011, from http://www.ccf.org.fj/article/ news/media1/press-release/562-public-order-amendment-decree-2012-restrictsbasic-freedoms

Rabuka and the reporter. (1994). Pacific Journalism Review, 1(1), pp. 20-22.

Raising investment a challenge. (2010, June 13). Fijilive.com. Retrieved 23 August 2010, from www.fm96.com.fj/iforum/?mod=read\&id=130610e2e6650513dc8bd b5e 20 ec5ed4ae $53 \mathrm{c} 7 \mathrm{~d} 0$

Reporter speaks out about trespassing case. (2010, May 5). Cook Islands News. Retrieved on 29 August 2011, from www.cinews.co.ck/2010/May/Wed05/features.htm

Response to global crises must prioritise zero tolerance for corruption. (2010, October 26). Transparency International. Retrieved 24 August 2011, from www.transparency.org/policy_research/surveys indices/cpi/2010/press

Robie, D. (2008, September 21). Muckraking honours and short memories. Café Pacific. [Web log post]. Retrieved on 25 August 2011, from http://cafepacific. blogspot.com/2008 0921 archive.html

Samoa PM says there will be no Fiji elections in 2014. (2012, January 27). Radio New Zealand International. Retrieved on 31 January 2012, from www.news.com. au/couriermail/

Samoa's Savali blasts 'propaganda-promoting journalists'. (2011, August 23). Pacific Media Centre Online. Retrieved on 25 August 2011, from www.pmc. aut.ac.nz/pacific-media-watch/fiji-samoas-savali-blasts-propaganda-promotingjournalists-7585

Scrap the bill. (2008, August 2). Cook Islands News in Pacific Media Watch. Retrieved on 24 August 2011, from http://kauri.aut.ac.nz:8080/dspace/bitstream/123456789/1025/1/cookis-media-bill-editorial.pdf

Singh, S. (2010). Life under Decree No. 29 of 2010: The Fiji Media Development Decree. Pacific Journalism Review, 16(2), pp. 147-149.

Singh, S., and Prakash, S. (2008). Storms in the Pacific: The volatile mix of democracy, politics and the media in three island states. In E. Papoutsaki \& U Harris (Eds.), South Pacific islands communications: Regional perspectives, local issues (pp. 117-132). Singapore: Asian Media Information and Communication Centre.

Swain, P. (2000). Development, Globalisation Civil Society and Non-Governmental organisations in the Pacific. Background paper prepared for the Stakeholders' Workshop on NGO capacity building, November 6-8, Port Vila, Vanuatu, Wellington: CID.

Synexe Consulting Limited. (2007). Impacts of corruption in the Pacific. Retrieved on 2 September 2011 from www.synexe.com/assets/Uploads/200701+Impacts + o $\mathrm{f}+$ Corruption + in + the + Pacific.pdf

Tanner, S., and McCarthy, N. (2001). Cultural specific training in corruption reporting for Pacific Island Journalists. Asia Pacific Media Educator, 11, pp. 113-128.

The media's role in combating corruption. (2011, May 6). Remarks at 2011 RAMSI media lunch. Retrieved on 3 September 2011 from www.ramsi.org/Media/docs/110506- 
2011-Media-Lunch-Special-Coordinator-Nicholas-Coppel-502589d4-5cb0-4c53a6f8-2ac6358304aa-0.pdf

The role of media in the fight against corruption. (2011, May 31). Island Sun. Retrieved on 3 September 2011, from www.islandsun.com.sb/index. php?option $=$ com_content\&view $=$ article $\&$ id $=2830$ :the-role-of-media-in-the-fightagainst-corruption \& catid $=43$ : speak-up\&Itemid $=88$

Think outside box to cover real stories about social change. (2009, October 30). Pacific Scoop. Retrieved on 24 August 2004, from http://pacific.scoop. co.nz/2009/10/think-outside-box-to-cover-real-stories-about-social-change-sayssayed-khaiyum/

Unions criticise being 'shut out' of pro-regime news. (2011, August 23). Pacific Media Centre Online. Retrieved on 24 August 2011, from www.pmc.aut.ac.nz/ pacific-media-watch/fiji-unions-criticise-being-shut-out-pro-regime-news-7584

US Department of State. (2011, April 8). 2010 Human Rights Report: Papua New Guinea. Retrieved on 3 September 2011 from www.state.gov/g/drl/rls/hrrpt/2010/ eap/154398.htm

Vanuatu publisher may appeal minister's sentence. (2011, July 4). Radio Australia. Retrieved on 24 August 2011, from www.radioaustralia.net.au/pacbeat/stories/201107/ s3260718.htm

Warning that Vanuatu corruption could lead to coup. (2011, March 14). Radio Australia. Retrieved on 25 August 2011, from www.radioaustralia.net.au/pacbeat/ stories/201103/s3163709.htm

Woods, J. (2010, May 5). It's still a fragile freedom. Cook Islands News. Retrieved on 24 August 2011, from www.cinews.co.ck/2010/May/Wed05/features.htm

Zwartz, N. (2010, February 27). Rampant logging 'destroying PNG'. The Age. Retrieved on 31 March 2012 from www.theage.com.au/environment/rampantlogging-png-20100226-p941.html

Shailendra Singh was formerly head of journalism in the School of Language, Arts and Media at the University of the South Pacific and a former editor of The Review news magazine. He has researched and written widely on Fiji corruption and governance issues for Inter Press Service and other news media. He is currently a doctoral candidate at the University of Queensland. An earlier version of this article was presented at the Media, Investigative Journalism and Technology conference at Auckland University of Technology in December 2010 shailendra.singh@uqconnect.edu.au 